\title{
17 $\beta$-Estradiol Inhibits Interleukin-6 Production by Bone Marrow-derived Stromal Cells and Osteoblasts In Vitro: A Potential Mechanism for the Antiosteoporotic Effect of Estrogens
}

\author{
Giuseppe Girasole, ${ }^{\star \ddagger}$ Robert L. Jilka, ${ }^{\ddagger}$ Giovanni Passeri,, Scott Boswell, ${ }^{\ddagger}$ George Boder, \\ Daniel C. Williams, and Stavros C. Manolagas \\ Section of Endocrinology and Metabolism, Veteran's Administration Medical Center and Department of Medicine and Biochemistry, \\ Indiana University, ${ }^{\ddagger}$ the Walther Oncology Center, ${ }^{*}$ and the Lilly Research Laboratories, ${ }^{\S}$ Indianapolis, Indiana 46202
}

\begin{abstract}
The effect of 17 $\beta$-estradiol on interleukin-6 (IL-6) synthesis was examined in murine bone marrow-derived stromal cell lines, normal human bone-derived cells, and nontransformed osteoblast cell lines from mice and rats. In all these cell types IL-6 production was stimulated as much as $\mathbf{1 0 , 0 0 0 - f o l d ~ i n ~ r e - ~}$ sponse to the combination of recombinant interleukin-1 (IL-1) and tumor necrosis factor $\alpha$ (TNF $\alpha)$. Addition of $17 \beta$-estradiol in the cultures exerted a dose-dependent inhibition of IL-1-, TNF-, and IL-1 + TNF-induced production of bioassayable IL-6. Testosterone and progesterone (but not 17 $\alpha$-estradiol) also inhibited IL-6, but their effective concentrations were two orders of magnitude higher than $17 \beta$-estradiol. $17 \beta$-estradiol also decreased the levels of the IL-6 mRNA. In addition, estradiol inhibited both TNF-induced IL-6 production and osteoclast development in primary bone cell cultures derived from neonatal murine calvaria. The TNF-stimulated osteoclast development was also suppressed by a neutralizing monoclonal antiIL-6 antibody. This in vitro evidence suggests, for the first time, a mechanistic paradigm by which estrogens might exert at least part of their antiresorptive influence on the skeleton. (J. Clin. Invest. 1992. 89:883-891.) Key words: osteoclast • osteoporosis • marrow stroma • interleukin-1 • tumor necrosis factor
\end{abstract}

\section{Introduction}

The rapid reduction of bone mass in females following the onset of the menopause, and the effective prevention or delay of the disease process by treatment with estrogens, are well established $(1,2)$. Nevertheless, the mechanism by which estrogens exert their protective influence on skeletal homeostasis remains elusive.

In spite of earlier difficulties, receptors for estrogens have been recently demonstrated in osteoblast-like cells, indicating that estrogens might exert their beneficial influence on skeletal homeostasis by direct actions on bone $(3,4)$. Consistent with the presence of receptors, $17 \beta$-estradiol stimulated alkaline phosphatase, the proliferation rate, IGF-1, and collagen

\footnotetext{
Address correspondence and reprint requests to Dr. Stavros C. Manolagas, VA Medical Center, Section of Endocrinology/Metabolism (111E), 1481 West 10th St., Indianapolis, IN 46202.

Received for publication 1 February 1991 and in revised form 15 November 1991.
}

The Journal of Clinical Investigation, Inc.

Volume 89, March 1992, 883-891
mRNA in rat osteogenic sarcoma cells, and rat calvaria and long bone cells $(5,6)$. In addition, estradiol inhibited the cAMP response to PTH $(6,7)$. Although these observations raise the possibility for anabolic effects of estrogens on the skeleton, they fall short of explaining the antiresorptive properties of estrogens.

A series of discoveries during the last few years has clearly established an important role of bone marrow in bone remodeling. Indeed, the bone-resorbing osteoclasts are derived from progenitors that originate from hematopoietic cells of the bone marrow, and bone-forming osteoblasts are of the same lineage as bone marrow-derived stromal cells (8-11). Furthermore, a network of autocrine and paracrine factors, produced in the microenvironment of bone by hematolymphopoietic, as well as by osteoblastic cells, has been shown to play a very important role in the formation and/or activation of osteoclasts. Since osteoclasts are derived from hematopoietic stem cells, it is not surprising that this network includes the colony-stimulating factors (CSF) ${ }^{1}$ and interleukins known to coordinate cell to cell communication in the hematolymphopoietic tissue. Most notably, IL-1 and tumor necrosis factor (TNF) are potent stimulators of bone resorption in vivo $(12,13)$, as well as in vitro (14-16).

More recent evidence indicates that IL-6, a cytokine involved in the regulation of diverse cellular functions in many tissues (17), might also play a role in bone resorption. Thus, IL-6 in combination with IL-3 stimulates the development of CFU-granulocyte macrophage (CFU-GM) (18), and IL-6, as well as IL-1 and $1,25(\mathrm{OH})_{2} \mathrm{D}_{3}$, stimulate early osteoclast precursor formation from cells present in CFU-GM colonies (19). Murine and rat osteoblasts produce IL-6, and this production can be stimulated by PTH (20-22). Moreover, IL- 6 stimulates the recruitment, as well as the formation, of osteoclasts and the release of ${ }^{45} \mathrm{Ca}$ from prelabeled mouse bone, and IL-1 and IL-6 induce bone resorption cooperatively $(20,22)$. Besides this in vitro evidence, an effect of IL- 6 on bone resorption in vivo has been shown by the studies of Black et al. (23).

Prompted by the above, and also by evidence that IL- 6 production is downregulated by $17 \beta$-estradiol in stromal cells of the human endometrium (24), we have examined in this study the hypothesis that estrogens might regulate the production of IL- 6 by bone marrow stromal cells and osteoblasts. We present evidence that murine bone marrow stromal cells, as well as normal human bone-derived cells and rat and murine

1. Abbreviations used in this paper: ANOVA, analysis of variance; CT, calcitonin; FBS, fetal bovine serum; GM-CSF, granulocyte macrophage-colony stimulating factor; hPTH, human PTH; TNF, tumor necrosis factor; TRAPase, tartrate resistant acid phosphatase. 
osteoblasts, produce IL-6, and that the production of IL-6 is stimulated several thousandfold by the combination of IL-1 and TNF. Furthermore, $17 \beta$-estradiol acts as an inhibitor of the induction of IL- 6 in these cells. The biological significance of this phenomenon was demonstrated by the observation of an inhibitory effect of $17 \beta$-estradiol on IL-6-mediated osteoclast development in primary cultures of bone cells derived from neonatal murine calvaria.

\section{Methods}

Chemicals and reagents. 17 $\beta$-estradiol, $17 \alpha$-estradiol, progesterone, and testosterone were purchased from Sigma Chemical Co. (St. Louis, MO). Recombinant human IL- $1 \beta$ was donated by the Immunex Research and Development Corp. (Seattle, WA) (sp act $10^{8} \mathrm{U} / \mathrm{mg}$ ), or the Biological Resources Branch of the Biological Response Modifiers Program, Division of Cancer Treatment/National Cancer Institute (sp. act. $1.8 \times 10^{7} \mathrm{U} / \mathrm{mg}$ ). Recombinant murine TNF- $\alpha$ was purchased from Genzyme Corp. (Boston, MA) (sp act $4 \times 10^{7} \mathrm{U} / \mathrm{mg}$ ), or Boehringer Mannheim Corp., Indianapolis, IN (sp act $6 \times 10^{7} \mathrm{U} / \mathrm{mg}$ ). The murine IL- 6 cDNA probe was a $1.2-\mathrm{kb}$ EcoRI-linkered cDNA in a pGEM vector with $\mathrm{T} 7$ promoter, and was a gift from Immunex Corp. Salmon calcitonin was purchased from Bachem, California (Torrence, CA), and was iodinated using Chloramine $T(25) .{ }^{125} I$ was purchased from Amersham Corp. (Arlington Heights, IL). A monoclonal antibody (rat anti-mouse IL-6 IgG, MP5-20F3) was generously provided by J. S. Abrams from the DNAX Research Institute of Molecular and Cellular Biology Inc. (Palo Alto, CA).

Cells and culture conditions. The +/+LDA11 stromal cell line was established from hematopoietically inactive long-term cultures. The donor mouse strain for this line was the congenic strain WCB6F1-+/+. The cell line was cloned by limiting dilution of adherent layers from long-term cultures. The cells were characterized by histochemical staining, and found to consist of a small percentage of alkaline phosphatase-positive cells, which, at confluence, could accumulate fat globules (putative adventitial reticular cells) typical of the preadipocyte phenotype of marrow stroma. These cells have been used extensively to demonstrate that they produce a variety of hematopoietic factors, including IL-6, LIF, as well as GM-CSF, and have also been used as the source of the isolation of the multifunctional c-kit ligand $(26,27)$. The MBA-13.2 bone marrow-derived murine stromal cell line was provided by Dr. Zipori from the Weismann Institute (Rehovot, Israel). This stromal cell line also makes type I and type IV collagen (28).

$+/+$ LDA11 cells were grown in $25-\mathrm{cm}^{2}$ plastic culture flasks in McCoy's 5A medium supplemented with $10 \%$ fetal bovine serum (FBS), penicillin $(100 \mu \mathrm{g} / \mathrm{ml})$, and streptomycin $(100 \mu \mathrm{g} / \mathrm{ml})$, at $37^{\circ} \mathrm{C}$ in $5 \% \mathrm{CO}_{2}$ in air. Cells were seeded in six-well plates at a density of 5 $\times 10^{5}$ /well in phenol red-free McCoy's $5 \mathrm{~A}$. At confluence, the medium was removed, cells were washed twice with PBS buffer and fresh medium containing $2 \%$ FBS, and the vehicle $(0.01 \%$ ethanol) was added without, or together with, various concentrations of steroids. The concentration of free $17 \beta$-estradiol in medium containing $2 \%$ FBS was 3.7 $\times 10^{-13} \mathrm{M}$, as determined by RIA. After $20 \mathrm{~h}$, human recombinant IL- $1 \beta$, or recombinant murine TNF $\alpha$, or the combination of IL- $1 \beta$ + TNF $\alpha$ were added, and cultures maintained for another $24 \mathrm{~h}$. At this stage, the media were collected by aspiration, spun for $5 \mathrm{~min}$ at $1,000 \mathrm{~g}$, and the supernatants were frozen at $-70^{\circ} \mathrm{C}$.

Human bone-derived cells were obtained from surgical samples from three otherwise normal individuals (two females and one male) undergoing corrective operation for scoliosis, with a protocol approved by the Indiana University Institutional Review Board. The bone sample from the two females was obtained from a rib, while the bone sample from the male was obtained from a vertebra. After stripping muscle and connective tissues, the specimens were minced with sharp scissors into small fragments $(\sim 0.1-1.0 \mathrm{~mm})$ and placed in DME/F12 (3:1) without phenol red, supplemented with $5 \%$ horse serum, $5 \%$ FBS, and vitamin $\mathrm{K}(1.0 \mu \mathrm{g} / \mathrm{ml})$. Cells grew out of the explants to confluency in $12 \mathrm{~d}$, at which time subcultures were obtained by brief digestion with $100 \times$ pancreatin (Gibco Laboratories, Grand Island, NY), and placed in fresh medium. Approximately $50-75 \%$ of the cells stained positively for alkaline phosphatase. These cells responded to human PTH (hPTH) with a dose-dependent elevation of cAMP. Representative results (of the cells from the 11-yr-old female) were as follows: $10 \mathrm{nM}$ $\mathrm{hPTH}=2.5 \pm 0.1 \mathrm{pmol} / 10^{5}$ cells; $20 \mathrm{nM} \mathrm{hPTH}=4.1 \pm 0.1 \mathrm{pmol} / 10^{5}$ cells; $40 \mathrm{nM} \mathrm{hPTH}=6.0 \pm 0.2 \mathrm{pmol} / 10^{5}$ cells.

Rat osteoblasts (line C3) were derived from adult rat calvaria and separated by mechanical, rather than enzymatic, methods. Details of the preparation of the cells and their phenotypic characteristics have been described earlier (29). These cells have phenotypic characteristics of osteoblasts, including the ability to mineralize in vitro. MC3T3-E1 nontransformed murine osteoblast-like cells (30) were provided to us by Dr. Gideon Rodan of Merck, Sharp, and Dohme Research Labs (West Point, PA).

After a relatively small number of passages (ranging between 5 and 10 for the different samples for the human and rat cells), serum was reduced to $2 \% \mathrm{FBS}$, and $2 \times 10^{5}$ cells were seeded in 6-well plates for 48 $h$ in the presence of the various agents.

For the preparation of primary cell cultures from neonatal murine bone, calvaria were dissected from 3-6-day old $\mathrm{C} 57 \mathrm{Bl} / 6 \mathrm{~J}$ mice and subjected to a modified collagenase digestion procedure as previously described (31). Cells ( $<5 \%$ of the total) and debris released during the first 10-min digestion period were discarded. Cells released during the subsequent $3 \times 20$-min digestion periods were pooled, filtered using $202 \mu$ opening polyethylene mesh, and then seeded at $0.2 \times 10^{6} / \mathrm{cm}^{2}$ in 1 - or $2-\mathrm{cm}^{2}$ wells in phenol red-free RPMI $+5 \%$ FCS. After overnight culture, 17 $\beta$-estradiol was added, and $24 \mathrm{~h}$ later, the medium was changed to $1 \%$ FCS in RPMI, and cytokines added. For experiments used for autoradiographic demonstration of the calcitonin receptor, cells were seeded onto $13-\mathrm{mm}$ round Thermanox tissue culture cover slips (Nunc, Inc., Naperville, IL) in 2- $\mathrm{cm}^{2}$ wells of a 24-well plate to allow processing and mounting for microscopy.

IL-6 bioassay. IL-6 levels in the culture supernatants were determined using the previously described B9 bioassay (32). Briefly, B9 cells $\left(5 \times 10^{3} /\right.$ well of a 96 -well plate) were cultured with a series of dilutions of the supernatants in a final volume of $100 \mu$ l of RPMI 1640, supplemented with $5 \times 10^{-5} \mathrm{M}$ of 2-mercaptoethanol, $10 \% \mathrm{FBS}, 100 \mathrm{U} / \mathrm{ml}$ penicillin, and $100 \mu \mathrm{g} / \mathrm{ml}$ streptomycin in flat-bottom microtiter plates. After $42 \mathrm{~h}, 0.5 \mu \mathrm{Ci}$ of $\left[{ }^{3} \mathrm{H}\right]$ thymidine was added. $6 \mathrm{~h}$ later, the cells were harvested and the radioactivity incorporated was determined. IL-6 was quantitated from a standard curve set up with known amounts of recombinant human or mouse IL-6. The anti-IL-6 monoclonal antibody completely inhibited the ability of the B9 cells to proliferate in response to recombinant mouse IL-6 (Fig. 1). In addition, we determined that B9 cells do not proliferate in response to IL-1 or TNF, and that antibodies to these two cytokines did not affect the cell proliferation in response to IL-6. Further, we established that neither 17 $\beta$ estradiol, nor the $0.01 \%$ ethanol used as vehicle in these experiments, had any effect on the bioassay (data not shown).

Northern blot hybridization. Confluent cultures of +/+LDA11 stromal cells were maintained for $20 \mathrm{~h}$ in the absence or in the presence of $17 \beta$-estradiol $\left(10^{-8} \mathrm{M}\right)$. Subsequently, human recombinant IL-1 $\beta$ (NCI $250 \mathrm{U} / \mathrm{ml}=1 \mathrm{nM}$ ) or murine recombinant TNF (Genzyme Corp., $500 \mathrm{U} / \mathrm{ml}=0.3 \mathrm{nM}$ ), or the combination of the two cytokines, or 8-bromo cAMP ( $1 \mathrm{mM})$ were added, and the cultures were continued for various time periods up to $10 \mathrm{~h}$. At this stage, cells were rinsed with cold PBS and immediately lysed in the presence of guanidinium isothiocyanate for isolation of RNA, by the method of Chomczynski and Sacchi (33). Total cellular RNA (30 $\mu \mathrm{g})$ was electrophoresed in $1 \%$ agarose in $\mathrm{Na}_{2} \mathrm{PO}_{4}$ buffer with $4 \%$ formaldehyde, then transferred to nitrocellulose. Blots were hybridized in $50 \%$ formamide to a full-length cDNA probe for murine IL-6 (Immunex Corp.) and washed with $0.5 \times$ sodium saline citrate at $52^{\circ} \mathrm{C}$. The probe was labeled with $\left[{ }^{32} \mathrm{P}\right] \mathrm{dCTP}$ by hexanucleotide primer labeling. Chinese hamster ovary $\mathrm{B}$ (CHO-B), a constitutively expressed housekeeping gene in the mouse, was used for control for the equivalence of loading (34). Relative levels of IL-6 


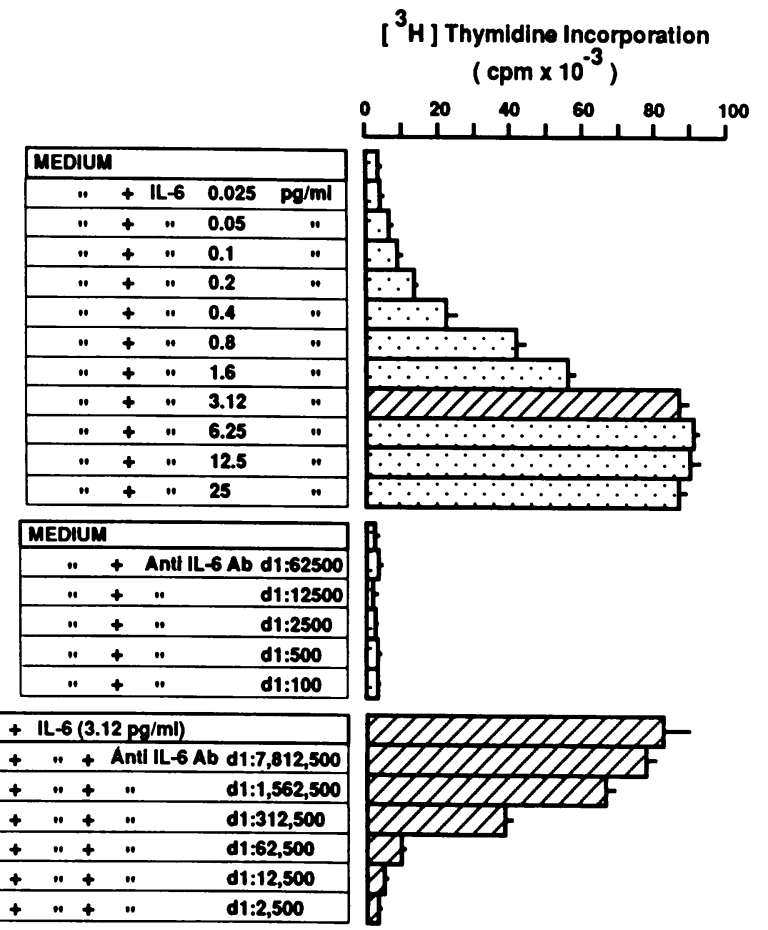

Figure 1. Specificity of the B9 cell bioassay for IL-6. Dose response of the B9 cell proliferation to recombinant murine IL-6, and the effect of an anti-IL-6 neutralizing antibody on this response. Each bar represents the mean $( \pm S D)$ of duplicate cultures.

mRNA were estimated by scanning densitometry, using a video densitometer (model 620; BioRad Laboratories, Richmond, CA), and were corrected for the corresponding levels of CHO-B mRNA for each lane.

Identification and quantitation of osteoclast-like cells in calvaria cell cultures. Autoradiographic detection of cells which bound salmon ${ }^{125} \mathrm{I}$ calcitonin (CT), and staining of calvaria cell monolayers for tartrate resistant acid phosphatase (TRAPase), were performed as previously described (25). Briefly, cell monolayers were rinsed with PBS $+5 \mathrm{mg} /$ $\mathrm{ml} \mathrm{BSA}$, and then incubated with $0.2-0.5 \mathrm{nM}^{125} \mathrm{I}-\mathrm{CT}$ in the above buffer at room temperature for $90 \mathrm{~min}$. Cells were extensively rinsed, dried, and then fixed with $2 \%$ glutaraldehyde in PBS for 10 min at $4^{\circ} \mathrm{C}$, rinsed in water, and then dried. TRAPase was visualized with reagents provided in kit 180 (Sigma Chemical Co.) and then dipped in NTB2 emulsion (Eastman Kodak Co., Rochester, NY). After 5-10 d, the slides were developed. TRAPase positive and/or ${ }^{125} \mathrm{I}-\mathrm{CT}$ binding cells were enumerated with the aid of an ocular grid, using bright field microscopy and $10 \times$ objective lens. Specific binding of ${ }^{125} \mathrm{I}-\mathrm{CT}$ was indicated by the lack of autoradiographic grains over TRAPase-positive cells when an excess of unlabeled CT ( $300 \mathrm{nM})$ was present during the incubation.

Statistical analyses. Tests for differences among treatments, i.e., across estrogen doses and different cytokines, were performed using analysis of variance (ANOVA). Because of the experimental design of the studies shown in Table I and Fig. 6, tests for estrogen dose effects were done pairwise within treatments after finding a significant overall $F$ test. For Fig. 2, an overall estrogen dose effect was calculated across treatments, using similar methods. For the rest of the experiments, data were analyzed by Student's $t$ test.

\section{Results}

Effects of 17ק-estradiol on IL-6 production by stromal cells. An experiment illustrating the production of IL- 6 by +/+LDA 11 marrow stromal cells in response to stimulation with TNF,
Table I. Percent Inhibition of Cytokine-induced IL-6 Production by $17 \beta$-Estradiol in $+/+$ LDA11 Stromal Cells

\begin{tabular}{cccc}
\hline $\begin{array}{c}17 \beta-E_{2} \\
\text { Concentration }\end{array}$ & $\begin{array}{c}\text { IL-1 }(1.8 \mathrm{nM}) \\
\mathrm{M} \pm \mathrm{SEM}\end{array}$ & $\begin{array}{c}\mathrm{TNF}(0.3 \mathrm{nM}) \\
\mathrm{M} \pm \mathrm{SEM}\end{array}$ & $\begin{array}{c}\text { IL-1 + TNF } \\
\text { M } \pm \text { SEM }\end{array}$ \\
\hline$M$ & $n$ & $n$ & $n$ \\
0 & 0 & 0 & 0 \\
$10^{-10}$ & $5.3 \pm 1.8(3)^{*}$ & $31.2 \pm 2.7(3)^{*}$ & $32.5 \pm 3.5(3)^{*}$ \\
$10^{-9}$ & $16.9 \pm 2.2(3)^{*}$ & $49.0 \pm 2.1(3)^{\ddagger}$ & $53.5 \pm 4.6(3)^{*}$ \\
$10^{-8}$ & $38.1 \pm 8.0(5)^{\ddagger}$ & $64.5 \pm 3.5(4)^{\| \prime}$ & $68.2 \pm 8.6(5)^{\prime \prime}$ \\
$10^{-7}$ & $37.5 \pm 8.8(2)^{\S}$ & - & $83.0 \pm 4.2(3)^{\| \prime}$ \\
& & & \\
\hline
\end{tabular}

Summary of replicate experiments to the one illustrated in Fig. 2. In each experiment, supernatants were tested as described in the legend of Fig. 2. Mean (M) \pm SEM, number of replicate experiments $(n)$ and level of statistically significant differences from cultures that received no estrogens, are shown. Statistical analysis was performed using ANOVA of logtransformed data. The transformation achieved the level of statistical normality necessary to appropriately apply ANOVA to this situation (50). The nests of estrogen effects were specific within each cytokine treatment group. ${ }^{*}$ No significant difference; ${ }^{\ddagger} P<0.01$; ${ }^{\S} P<0.05 ; " P<0.001$, compared to cultures not treated with $17 \beta$-estradiol.

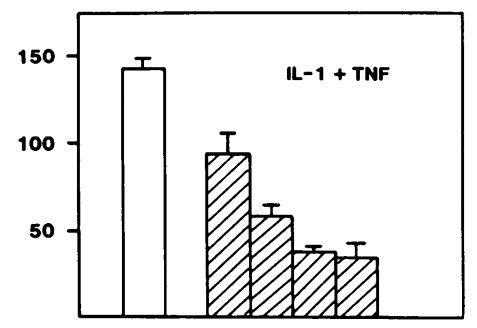

Figure 2. Effects of $17 \beta$ estradiol on cytokineinduced IL-6 production by murine bone stromal cells. $+/+-$ LDA11 cells grown in phenol red-free McCoy's 5A medium were treated for $20 \mathrm{~h}$ with $17 \beta$-estradiol, and

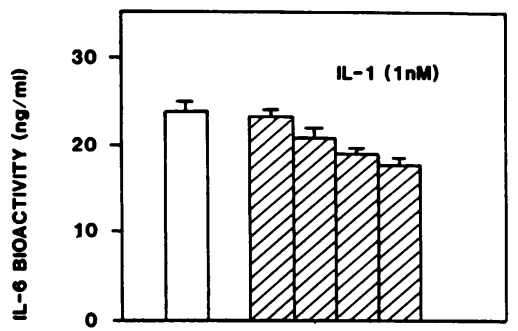
then recombinant murine TNF, or recombinant human IL- $1 \beta$, or the combination of the two were added, and cultures maintained for another $24 \mathrm{~h}$. Two samples of the supernatant from a single culture of the +/+LDA 11 cells were serially diluted (610 dilutions). Each dilution was then incubated with B9 cells, and its effect on the B9 cell proliferation was determined using $\left[{ }^{3} \mathrm{H}\right]-$ thymidine incorporation. Values shown are the mean $( \pm S D)$ of four readings obtained from the two dilutions (from each sample) which fell on the linear part of the standard curve, and thus the SD reflect error due to the IL-6 assay. For all three cytokine treatments (TNF, IL-1, TNF + IL-1), there was a significant overall estrogen effect $(P<0.025)$; the lowest concentration $\left(10^{-10}\right)$ however, was not significantly different from the control culture. All other concentrations were significantly different $\left(10^{-9} \mathrm{M}\right.$ $P<0.05 ; 10^{-8} \mathrm{M} P<0.009 ; 10^{-7} \mathrm{M} P<0.003$ ). 
IL-1, or the combination of these two cytokines and the effect of $17 \beta$-estradiol on these phenomena, is shown in Fig. 2. Under basal conditions ( $2 \%$ serum), these cells produced a very small amount of IL-6 (ranging from undetectable to a maximum of $0.30 \mathrm{pg} / \mathrm{ml}$ ). Culture supernatants of cells treated with either human recombinant IL- $\beta \beta$ or murine recombinant TNF $\alpha$, however, contained dramatically higher IL-6 levels, compared with cultures maintained in the absence of these agents. In several replicate experiments (summarized in Table I), the IL$1 \beta$ and TNF $\alpha$-mediated increment in IL- 6 ranged between 200-2,000-fold and 5-20-fold, respectively. Furthermore, the combination of IL-1 and TNF elicited IL-6 levels that were 10,000-fold higher, compared with baseline values $(P<0.001$ for a difference in IL-6 production among the three cytokine treatments). Addition of $17 \beta$-estradiol to these cultures had no effect on basal production of IL-6 (data not shown). However, $17 \beta$-estradiol produced a significant inhibition of IL-6 production induced by either IL-1, TNF, or the combination of IL-1 + TNF. (Fig. 2 and Table I). The effect of estradiol was dose-dependent in the range of $10^{-10} \mathrm{M}-10^{-7} \mathrm{M}$, and appeared to be more potent in inhibiting the IL-6 production induced by TNF and IL-1 + TNF, as compared with IL-1 alone.

$17 \alpha$-estradiol, the biologically inactive isomer of $17 \beta$ estradiol, had no influence on IL-6 production in these experiments (Fig. 3). Progesterone and testosterone inhibited cytokine-stimulated IL- 6 production, but their effect was apparent at concentrations two orders of magnitude higher than that of $17 \beta$-estradiol.

A similar dose-dependent inhibition of IL-1 + TNF-induced IL- 6 by $17 \beta$-estradiol to that seen in the $+/+$ LDA 11 cells

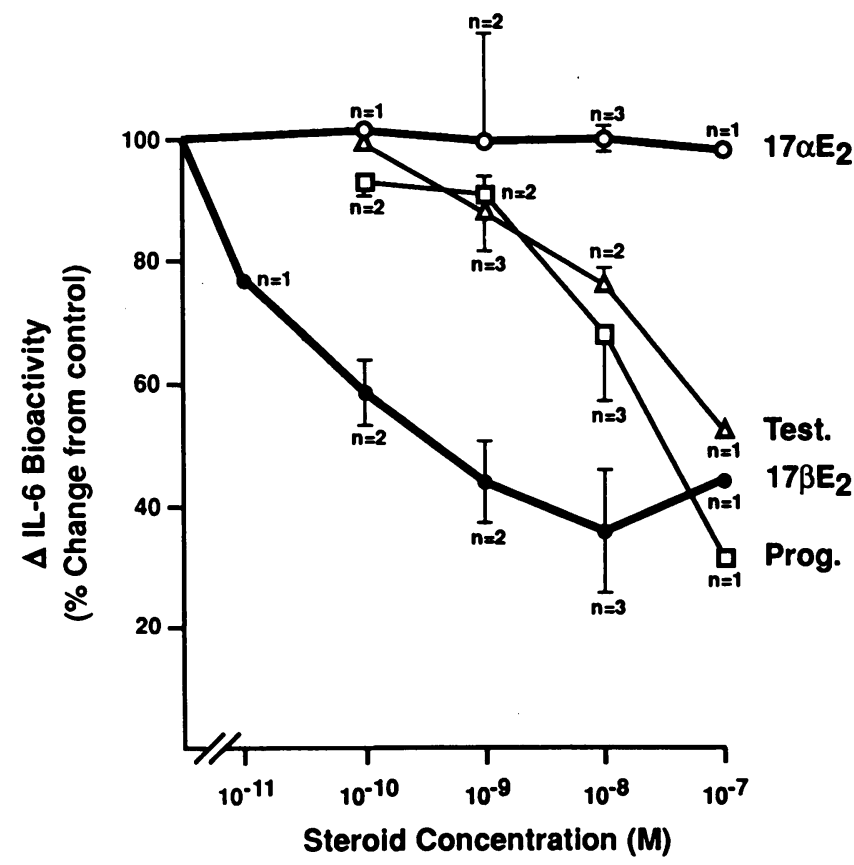

Figure 3. Specificity of sex steroid inhibition of IL-6 production. +/+LDA11 cells were treated with the indicated steroids for $20 \mathrm{~h}$, after which IL-1 (Immunex Corp.) + TNF (Genzyme Corp.), at the concentration of $1.8 \mathrm{nM}$ and $0.3 \mathrm{nM}$, respectively, were added, and the cultures continued for another $24 \mathrm{~h}$. Each point represents the mean ( \pm SEM) IL-6 levels in replicate experiments $(n)$, expressed as a percentage of untreated cultures. was also observed in the murine MBA-13.2 stromal cell line (28) (Fig. 4, B). Using the MBA-13.2 cells, we also observed that the inhibitory effect of $17 \beta$-estradiol on IL-6 became apparent $\sim 5 \mathrm{~h}$ after IL-6 induction by the combination of $0.3 \mathrm{nM}$ TNF and $0.5 \mathrm{nM}$ IL-1, and persisted through a subsequent exponential rise in IL-6 at 10, 18, and 24h (data not shown).

To investigate whether $17 \beta$-estradiol affected the level of IL- 6 mRNA, confluent +/+LDA11 cells were maintained in the presence or absence of $10^{-8} \mathrm{M} 17 \beta$-estradiol for $20 \mathrm{~h}$, and were then stimulated with the combination of IL-1 (Immunex Corp., $500 \mathrm{U} / \mathrm{ml}=1.8 \mathrm{nM}$ ) and TNF (Genzyme Corp., 500 $\mathrm{U} / \mathrm{ml}=0.3 \mathrm{nM}$ ), or with the cAMP analogue 8-bromo cAMP $(1 \mathrm{mM})$ (Fig. $5 A)$, or with IL-1 (NCI, $250 \mathrm{U} / \mathrm{ml}=0.5 \mathrm{nM})$, or TNF alone (Genzyme Corp., $500 \mathrm{U} / \mathrm{ml}=0.3 \mathrm{nM}$ ) (Fig. $5 \mathrm{~B}$ ). Total RNA was isolated at various time periods following the addition of the stimuli, and mRNA levels for IL- 6 were determined by Northern blot hybridization with a murine cDNA probe for IL-6 (Fig. 5). In cultures not stimulated by cytokines, we were unable to detect IL-6 mRNA. However, IL-6 was detected in cultures stimulated with the cytokines. The amount of the IL-6 mRNA was 25-fold greater in stromal cells treated with IL-1 + TNF, compared with the cultures that were treated with IL-1 alone, with a peak response to IL-1 + TNF at $4 \mathrm{~h}$ (not shown). Fig. $5 A$ shows that $17 \beta$-estradiol pretreatment caused a $49 \%$ decrease in IL-6 mRNA induced by 4-h exposure to the combination of IL- $1 \beta$ and TNF. Analysis of secreted IL-6 levels in the same experiment at $4 \mathrm{~h}$ indicated a $66 \%$ decrease in bioactivity. The effect of $17 \beta$-estradiol on 8-bromo cAMP-induced IL-6 mRNA was also examined to determine whether other pathways leading to IL-6 production were affected. As shown in Fig. $5 A, 17 \beta$-estradiol inhibited 8-bromo cAMP induced IL- 6 mRNA, by $48 \%$, and this corresponded with an inhibition of bioassayable IL-6 of $56 \%$.

In a separate experiment, we examined whether $17 \beta$ estradiol influences IL- 6 mRNA induced by either IL-1 or TNF, when these agents are used individually (Fig. $5 \mathrm{~B}$ ). Because of the relatively small levels of IL- 6 induced by IL-1 or

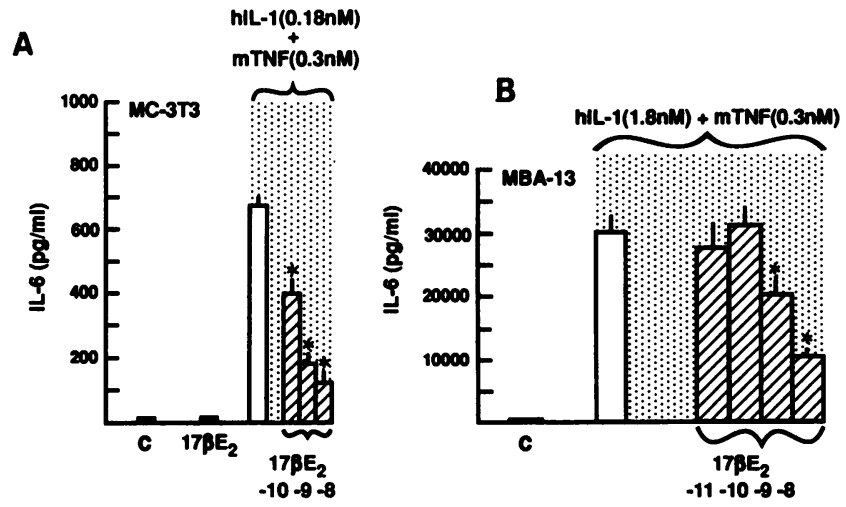

Figure 4. Effect of $17 \beta$-estradiol on IL-6 production by murine MC3T3 osteoblasts and MBA-13.2 stromal cells. Murine MC3T3 osteoblast-like cells $(A)$ or murine MBA-13.2 stromal cells $(B)$ were preincubated with the indicated concentrations of $17 \beta$-estradiol for $20 \mathrm{~h}$, and then stimulated with the indicated cytokines for $24 \mathrm{~h}$. Each bar represents the mean $( \pm S D)$ of duplicate cultures. Similar results were obtained in a separate experiment for both cell lines. *Statistically significant differences from the untreated cultures (Student's $t$ test); $P$ $<0.001$. 

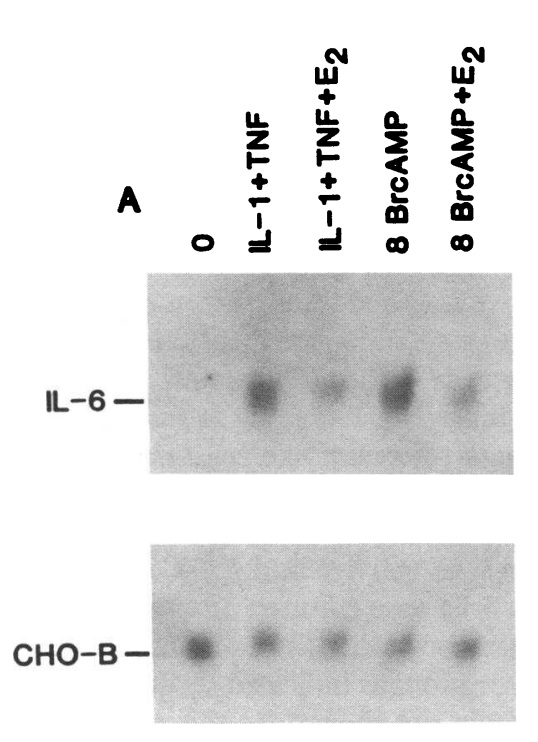
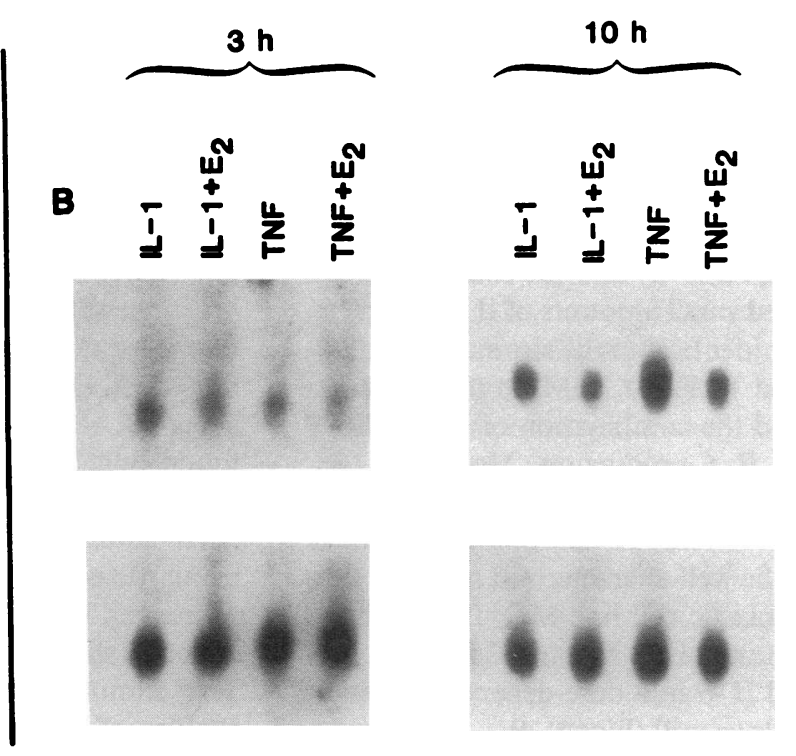

Figure 5. Effect of $17 \beta$-estradiol on IL-6 mRNA in $+/+$ LDA 11 cells. +/+LDA11 stromal cells were treated as indicated in the text, and total RNA was isolated by the method of Chomczynski and Sacchi (33). CHO-B a constitutively expressed housekeeping gene in the mouse, was used for control for the equivalence of loading. Filters in experiment $A$ were exposed overnight; for the 3-h time point of experiment B, the filters were exposed for $2 \mathrm{wk}$; for the 10-h time point, the filters were exposed for $24 \mathrm{~h}$. Similar results were reproduced in another two experiments.
TNF alone, as opposed to the combination of these cytokines, detection of the IL-6 message required longer exposure of the filters. IL-6 mRNA was detectable at $3 \mathrm{~h}$ poststimulation with either IL-1 or TNF, and its levels increased progressively up to $10 \mathrm{~h}$ after stimulation. An effect of $17 \beta$-estradiol on IL-6 mRNA was noted at both $3 \mathrm{~h}$ and $10 \mathrm{~h}$; in the case of IL-1, a $34 \%$ and $37 \%$ inhibition, respectively, was observed, while in the case of TNF, the inhibitory effect at $3 \mathrm{~h}$ was $25 \%$, and at 10 h was $26 \%$ (Fig. $5 \mathrm{~B}$ ). Unlike the results of the experiments shown in Fig. 2 and Table I, where IL-1 induced much greater levels of bioassayable IL-6 in +/+LDA 11 cells, compared with TNF, the levels of IL-6 mRNA induced in response to IL-1 versus TNF in this experiment were similar. This apparent in- consistency might be explained in part by the fact that a different preparation of IL-1 and a lower concentration of this cytokine was used in the mRNA experiments. In any event, 17 $\beta$ estradiol inhibited bioassayable IL-6 (measured at $10 \mathrm{~h}$ following stimulation) in this experiment by $45 \%$ in the case of IL-1, and $58 \%$ in the case of TNF. These data support the possibility that $17 \beta$-estradiol inhibits IL-6 production in these cells by decreasing the level of the mRNA, but further studies will be required to determine the precise molecular mechanisms of the phenomena.

Effects of $17 \beta$-estradiol on IL-6 production by osteoblastlike cells. Because of the findings in the bone marrow-derived stromal cells, we proceeded to examine whether osteoblastic

Table II. Effect of 17ß-Estradiol on Cytokine Induced IL-6 Production by Nontransformed Human Bone Cells

\begin{tabular}{|c|c|c|c|c|c|}
\hline \multirow[b]{3}{*}{ Treatment } & \multirow[b]{3}{*}{ (11 yr 9) } & \multicolumn{4}{|c|}{$\mathrm{IL}-6$ (ng/ml) } \\
\hline & & \multicolumn{2}{|c|}{$(16$ yr 8$)$} & \multicolumn{2}{|c|}{ (21 yr \&) } \\
\hline & & Experiment 1 & Experiment $2^{*}$ & Experiment 1 & Experiment $2^{*}$ \\
\hline Med alone & $0.12 \pm 0.004$ & $0.13 \pm 0.02$ & $0.03 \pm 0.005$ & $0.08 \pm 0.01$ & $0.11 \pm 0.02$ \\
\hline$+\mathrm{TNF}$ & $3.30 \pm 0.35$ & $6.19 \pm 0.73$ & $0.47 \pm 0.06$ & $1.96 \pm 0.13$ & $0.89 \pm 0.19$ \\
\hline$+\mathrm{TNF}+\mathrm{E}_{2}$ & $2.04 \pm 0.23^{\ddagger}$ & $2.95 \pm 0.28^{\ddagger}$ & Not Tested & $1.20 \pm 0.23^{8}$ & $0.64 \pm 0.08^{\ddagger}$ \\
\hline+ IL-1 & $23.94 \pm 2.70$ & $88.68 \pm 2.98$ & $22.64 \pm 0.08$ & $27.11 \pm 1.87$ & $108.64 \pm 14.11$ \\
\hline$+\mathrm{IL}-1+\mathrm{E}_{2}$ & $15.31 \pm 1.99^{\S}$ & $38.54 \pm 7.05^{\ddagger}$ & $7.33 \pm 3.34^{\ddagger}$ & $28.54 \pm 3.93^{\prime \prime}$ & $33.65 \pm 5.85^{\ddagger}$ \\
\hline +IL-1 + TNF & $85.31 \pm 7.85$ & $205.44 \pm 5.96$ & $26.90 \pm 3.68$ & $68.80 \pm 8.26$ & $110.62 \pm 8.37$ \\
\hline$+\mathrm{IL}-1+\mathrm{TNF}+\mathrm{E}_{2}$ & $34.55 \pm 5.90^{\ddagger}$ & $117.82 \pm 9.19^{\ddagger}$ & $22.04 \pm 4.81^{11}$ & $44.47 \pm 0.95^{\S}$ & $79.44 \pm 14.21$ \\
\hline
\end{tabular}

Effects of $17 \beta$-estradiol on IL-6 production by normal human bone cells. Human bone cells were obtained from surgical samples from three otherwise normal individuals (two females and one male) undergoing corrective operation for scoliosis. The age and sex of each donor is indicated in the parentheses. After a relatively small number of passages (ranging between 5 and 10 for the different samples), serum was reduced to $2 \% \mathrm{FBS}$, and $2 \times 10^{5}$ cells were seeded in 48-well plates for $48 \mathrm{~h}$ in the presence of the indicated agents [murine TNF (Genzyme Corp.) 0.3 $\mathrm{nM}$ human rIL-1 (Immunex Corp.) $0.18 \mathrm{nM} ; 17 \beta$-estradiol $\left.10^{-8} \mathrm{M}\right]$. Values indicate mean $( \pm \mathrm{SD})$ of two different dilutions of supernatants from one culture well; each dilution tested in duplicate in the proliferation of the B9 cells. *Different IL-1 preparation was used in these experiments. ${ }^{\ddagger} P<0.001 ;{ }^{\$} P<0.005$; "Not significant; ${ }^{\top} P<0.01$. $P$ values refer to comparisons between stimulatory agent alone vs. stimulatory agent $+\mathrm{E}_{2}$, using student's $\mathrm{T}$ test. 
cells produce IL-6, and whether IL-6 production is regulated by $17 \beta$-estradiol. In these experiments, we utilized human bonederived cells, as well as rat and murine osteoblastic cells. These cells, with the exception of the murine MC3T3-E1 cell line, exhibited approximately 10 -fold greater IL-6 response to IL-1 than either of the murine stromal cell lines. Thus, for the purpose of comparison with the stromal cells, we arbitrarily chose to use 10-fold less IL-1 in these experiments. Nontransformed human bone-derived cells (Table II) and rat osteoblastic cell (Table III) cultures produced small amounts of IL-6 under basal conditions. In a manner identical to the stromal cells, addition of IL- $1 \beta(0.18 \mathrm{nM})$ and TNF $\alpha(0.3 \mathrm{nM})$ to these cultures stimulated IL-6 release, and the combination of IL-1 + TNF had a synergistic effect on IL-6 production. Moreover, 17 $\beta$ estradiol $\left(10^{-8} \mathrm{M}\right)$ inhibited the IL-1-, TNF-, and IL-1 + TNFinduced IL- 6 in these preparations. In addition to the above cell lines, we have utilized the well-characterized neonatal murine calvaria-derived osteoblastic cell line MC3T3-E1 which, similar to the $\mathrm{C} 3$ rat line, mineralizes in vitro (35). We found that $17 \beta$-estradiol inhibited IL- 6 in a dose-dependent fashion $\left(10^{-10}-10^{-8} \mathrm{M}\right)$ in these cells as well (Fig. $\left.4, A\right)$.

Effects of 17B-estradiol on IL-6 production and osteoclastlike cell development in primary cultures from neonatal murine calvaria. Prompted by the evidence for the inhibitory effect of estrogen on IL-6 in the stromal and the osteoblastic cells, we investigated whether similar phenomena occur in primary cell cultures containing the diverse range of cells that are normally present in the bone microenvironment. For these studies, we utilized primary bone cell cultures prepared by collagenase digestion of neonatal murine calvaria. As described earlier, these cultures contain osteoclast progenitors, as well as cell types that both secrete, and respond to, several cytokines and colony stimulating factors $(25,36)$. Because of these characteristics, this multicellular system provided us with the opportunity to test whether IL-6 inhibition by $17 \beta$-estradiol was relevant to osteoclast development.
Similar to the case of the cell lines, IL-1 and TNF stimulated IL-6 production from these cultures, and the effects of the two cytokines were synergistic (data not shown). We found that $17 \beta$-estradiol inhibited TNF-induced IL-6 production (Fig. 6, $B$ ). In four replicate experiments, the mean value of this inhibition was $45 \% \pm 5$ (SEM); $P<0.05$. However, under the same experimental conditions, $17 \beta$-estradiol did not reproducibly influence IL-1- or IL-1 + TNF-induced IL-6. As expected, IL-6 bioactivity was completely inhibited by the anti-IL-6 antibody.

In the same cultures, we searched for the effects of TNF on osteoclast development and the influence of $17 \beta$-estradiol on this effect. Osteoclast-like cells in the cultures were identified, using TRAPase staining and ${ }^{125}$ I-CT binding as markers. We found that TNF stimulated osteoclast-like cell formation. A representative dark field microscopic image of the TNF-stimulated cultures is shown in Fig. 7, which illustrates the simultaneous detection of TRAPase activity and ${ }^{125} \mathrm{I}-\mathrm{CT}$ binding. Moreover, when calvaria cells were cultured on smooth cortical bone slices, as we described earlier (25), we observed that TNF stimulated bone resorption, as indicated by quantitative analysis of pits formed (data not shown). In this and several replicate experiments of TNF-stimulated cultures, we found that $\sim 80 \%$ of the TRAPase positive cells display CT binding. More important, we found that $17 \beta$-estradiol at $10^{-8} \mathrm{M}$ concentration inhibited the TNF-induced osteoclast development (Fig. 6, $A$ ). In five replicate experiments, the mean value of the percentage of the inhibition was $42 \% \pm 12$ (SEM); $P<0.05$. Similar to $17 \beta$-estradiol, the neutralizing anti-IL-6 monoclonal antibody, MP5-20F3, also inhibited TNF-induced osteoclastic cell formation. Nevertheless, the anti-IL-6 antibody had no influence on the IL-1-stimulated osteoclast development. Because these findings suggested that the inhibitory effect of estrogen on osteoclast development induced by TNF could be mediated via the inhibition of IL-6 production in these cultures, we sought supportive evidence for the involvement of IL-6 in TNF-mediated osteoclast formation. We found that the

Table III. Effect of Estrogens on Cytokine-Induced IL-6 Production by Nontransformed Adult Rat Calvaria Cells

\begin{tabular}{|c|c|c|c|}
\hline \multirow[b]{2}{*}{ Treatment } & \multicolumn{3}{|c|}{$\mathrm{IL}-6$ (ng/ml) } \\
\hline & Experiment $1^{*}$ & Experiment $2^{\ddagger}$ & Experiment $3^{\ddagger}$ \\
\hline Medium & $0.01 \pm 0.001$ & $0.06 \pm 0.001$ & $0.08 \pm 0.01$ \\
\hline Medium + TNF & $0.63 \pm 0.02$ & $0.53 \pm 0.10$ & $5.69 \pm 0.40$ \\
\hline Medium + TNF $+17 \beta-E_{2}$ & $0.60 \pm 0.02^{\S}$ & $0.35 \pm 0.06^{\S}$ & $3.49 \pm 0.10^{\prime}$ \\
\hline Medium $+\mathrm{TNF}+17 \alpha-\mathrm{E}_{2}$ & - & - & $4.77 \pm 0.37^{\S}$ \\
\hline Medium + IL-1 & $6.27 \pm 0.21$ & $14.57 \pm 2.85$ & $26.55 \pm 0.62$ \\
\hline Medium + IL-1 + 17 $\beta-\mathrm{E}_{2}$ & $3.96 \pm 0.09^{\| \prime}$ & $8.74 \pm 1.98^{\prime \prime}$ & $8.91 \pm 0.22^{\prime \prime}$ \\
\hline Medium + IL-1 $+17 \alpha-\mathrm{E}_{2}$ & - & - & $28.59 \pm 1.25^{\S}$ \\
\hline Medium + IL-1 + TNF & $21.10 \pm 0.77$ & $77.28 \pm 5.29$ & $83.58 \pm 0.42$ \\
\hline Medium + IL-1 + TNF $+17 \beta-\mathrm{E}_{2}$ & $12.22 \pm 0.56^{\prime \prime}$ & $44.95 \pm 7.22^{\prime}$ & $22.81 \pm 1.35^{\prime \prime}$ \\
\hline Medium + IL-1 + TNF $+17 \alpha-\mathrm{E}_{2}$ & - & - & $82.53 \pm 1.40^{8}$ \\
\hline
\end{tabular}

Each value represents results from one cell culture; each supernatant has been tested in two dilutions, each dilution in duplicate. \pm SEM refers to the quadruplicate results of the bioassay, the exception being Experiment 2. Here, values are the mean of three cultures, each supernatant in duplicate dilutions, each dilution in duplicate results of the bioassay.

* Murine TNF (Genzyme Corp.) $0.3 \mathrm{nM}$; human rIL-1 (Immunex Corp.) $0.18 \mathrm{nM} ; 17 \beta$-estradiol $19^{-8} \mathrm{M}$.

‡ Murine TNF (Genzyme Corp.) $0.3 \mathrm{nM}$; human rIL-1 (N.C.I.) $0.01 \mathrm{nM} ; 17 \beta$-estradiol $10^{-8} \mathrm{M} ; 17 \alpha$-estradiol $10^{-7} \mathrm{M}$.

${ }^{8}$ Not significant; ' $P<0.005$; $P<0.001$. $P$ values refer to comparisons between stimulatory agent alone vs stimulatory agent + steroid, using Student's T test. 

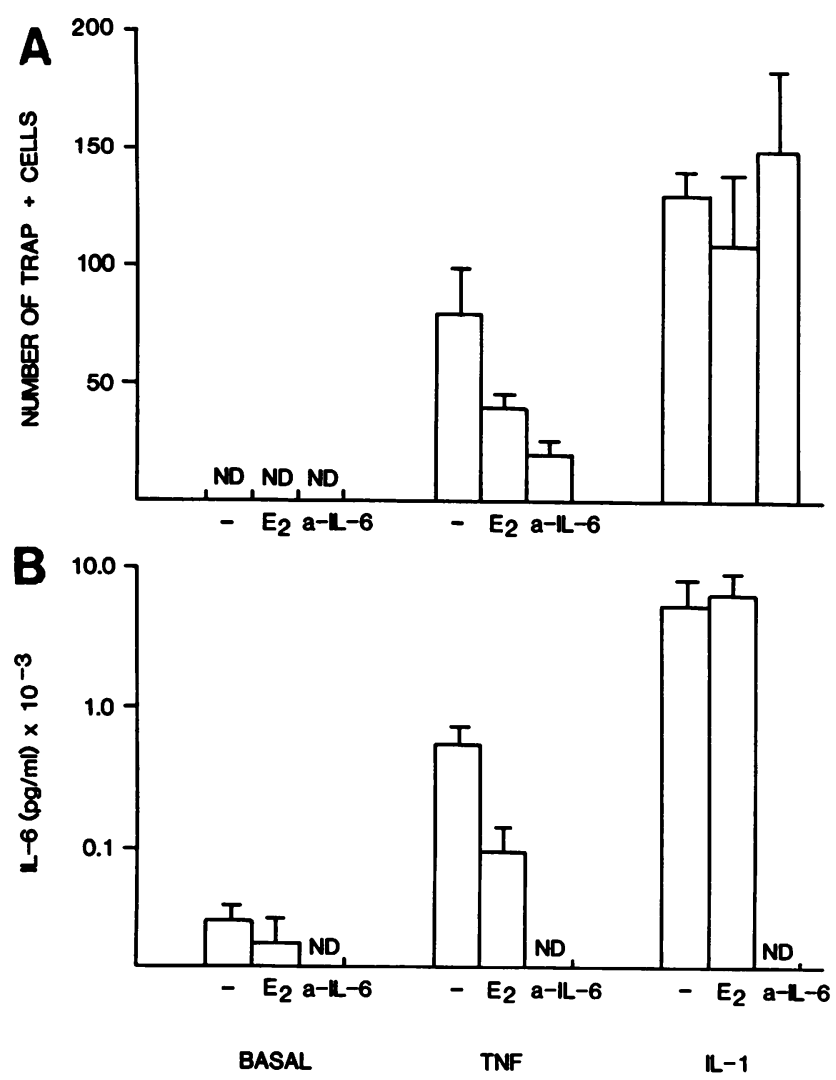

Figure 6. Effect of $17 \beta$-estradiol and anti-IL-6 on TNF-stimulated IL- 6 production and the development of osteoclast-like cells. Neonatal murine calvaria cells were seeded at $2 \times 10^{5} / \mathrm{cm}^{2}$ in $2-\mathrm{cm}^{2}$ wells, and cultured for $24 \mathrm{~h}$ in medium alone, medium containing $10^{-8} \mathrm{M}$ $17 \beta$-estradiol, or medium with $5 \mu \mathrm{g} / \mathrm{ml}$ of the rat anti-mouse IL- 6 monoclonal antibody, MP5-20F3. At the end of the 24-h period, either TNF (Boehringer Mannheim Corp.), 30 pM, or IL-1 (NCI), 20 $\mathrm{pM}$, was added in the cultures, and the experiment was continued for another $48 \mathrm{~h}$ at which stage supernatants were collected, and IL-6 was determined $(B)$. Medium was then changed and cultures were continued for another $48 \mathrm{~h}$, at which stage cells were fixed and stained with naphthol AS-BI phosphoric acid, diazotized pararosaniline, and sodium tartrate $\mathrm{pH} 5.2$ to visualize osteoclast-like cells $(A)$. Bars indicate mean $( \pm \mathrm{SD})$ of duplicate cultures.

dose-response curve of IL-6 production and the dose response of osteoclast formation in response to TNF were superimposed between the range of 3-300 pM concentration of TNF (data not shown).

\section{Discussion}

The data presented in this report indicate that stromal cells derived from bone marrow and osteoblasts produce IL-6 in response to stimulation by IL- 1 and TNF, and that in both cell types this production is inhibited by estrogens. These findings were highly reproducible across a variety of experimental models of bone cells from humans and rodent sources. From these in vitro data we cannot be certain whether the observed effect is pharmacologic rather than physiologic. Nevertheless, in the stromal cells and the established osteoblastic cell line MC-3T3 in which we have been able to perform extensive dose-response studies, we noted statistically significant effects of $17 \beta$ - estradiol at concentrations of $10^{-10}$ and $10^{-9} \mathrm{M}$, which correspond with the affinity of this steroid for its receptor $\left(K_{\mathrm{d}} \approx\right.$ $0.3-0.6 \mathrm{nM})$. This evidence favors the possibility that the effect of $17 \beta$-estradiol on IL-6 is of physiologic relevance.

Analysis of mRNA levels in one of the stromal cell lines (+/+LDA 11) indicated that estrogen caused a decrease in IL-6 mRNA levels induced by either cytokines or cAMP analogues. Further studies are needed to establish whether the effects of estrogens on IL-6 mRNA are transcriptional or posttranscriptional. Similarly, further studies will be needed to determine whether the effects of estrogens on IL- 6 mRNA can fully account for the effects of estrogens on bioassayable IL-6. In view of the observation that $17 \beta$-estradiol inhibited 8-bromocAMP-induced IL-6 mRNA in our experiments, future studies will be also needed to explore the possibility that estrogens affect IL- 6 induced not only by cytokines, but by other agents that stimulate IL-6 production via this intracellular mediator.

Using a mixed cell population from neonatal murine calvaria that contains the cells occurring normally in the bone microenvironment, including osteoclast progenitors, we observed that TNF stimulated osteoclast development, and that a significant proportion of this effect was mediated by IL-6. More importantly, we found that the inhibiting effect of estrogens on IL-6 production in TNF-stimulated cultures was associated with an inhibition of osteoclast development in response to TNF. These findings are in line with the reports of Lowik et al. (20), Ishimi et al. (22), Black et al. (23), and Kurihara et al. $(19,37)$, indicating a role of IL-6 in osteoclast development and bone resorption. In contrast to the above evidence, Al-Humidan et al. (38) found that IL-6 did not affect ${ }^{45} \mathrm{Ca}$ release, and concluded that IL-6 has no role in bone resorption. This apparent discrepancy is probably due to several factors, the most likely of which is that, in their study, Al-Humidan et al. used neonatal murine calvaria (as opposed to the fetal and marrowderived bone cultures of the other studies), which likely contain a limited number of immature myeloid progenitors that are the targets for IL-6 $(18,19)$.

In our work, we observed that the TNF-induced IL-6 production in the murine stromal cell line $+/+$ LDA 11 was more sensitive to inhibition by $17 \beta$-estradiol, compared with the IL1 -induced IL- 6 production in these cells, and that in the murine calvaria cells estrogens could only inhibit the TNF-stimulated IL- 6 production. In all cell systems examined in this study, IL-1 and TNF acted synergistically to stimulate IL-6 production. Similar observations of a synergistic stimulation of IL- 6 by IL- 1 and TNF production have been made in fibroblasts (39). Therefore, these two cytokines may act via different mechanisms in inducing IL-6 production. Considering this, it is likely that the TNF-stimulated signal pathway leading to IL-6 production is more sensitive to estrogens than the IL-1-stimulated signal pathway. Whether this difference in sensitivity is responsible for the apparent lack of an effect of estrogens on IL-1-stimulated IL- 6 production observed in the mixed calvaria cell experiments, or to as yet undefined differences between the primary mixed cell cultures and the cell lines, is unclear.

In the mixed cells from the neonatal calvaria, $17 \beta$-estradiol as well as the anti-IL-6 antibody inhibited the TNF-, but not the IL-1-induced osteoclast development. It is therefore likely that IL-1 utilizes IL-6-independent mechanisms to induce its effects on osteoclast development, at least in the calvaria system. Of course, a better understanding of the precise role of 


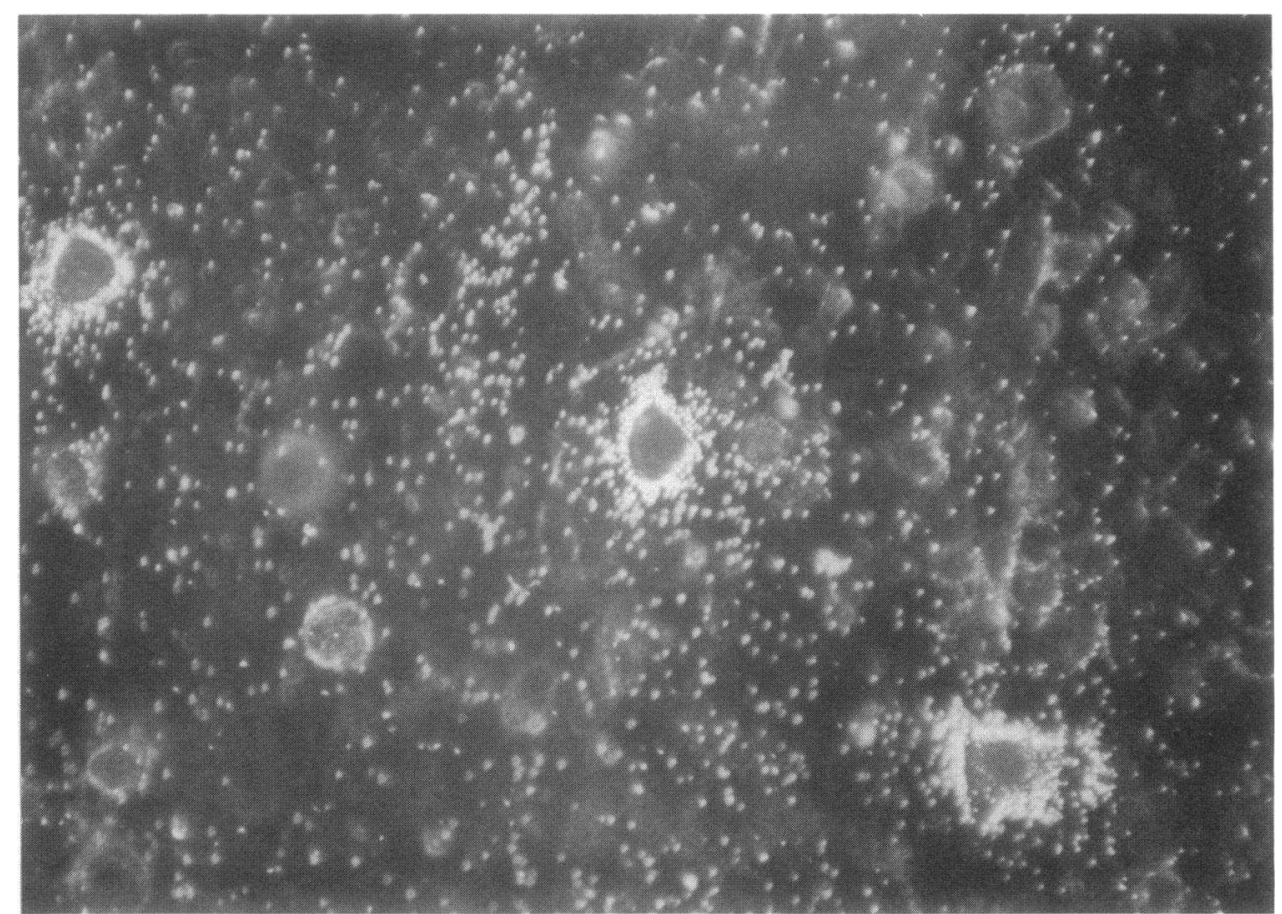

Figure 7. Dark field microscopy of TNF-induced osteoclast-like cells. Neonatal murine calvaria cells were cultured in the presence of TNF, as described in Fig. 6 on Thermanox coverslips. Cells were processed to visualize TRAPase and ${ }^{125} \mathrm{I}-\mathrm{CT}$ as described in methods. Most TRAPase positive cells (red) displayed autoradiographic grains indicating bound ${ }^{125} \mathrm{I}-\mathrm{CT}$ (white in this dark field image). $\times 331$. various mediators in the different steps of the differentiation pathway leading ultimately to osteoclast development will be required before this contention can be validated.

At this stage, the relevance of the presented evidence for a link between cytokines, estrogens, and osteoclast development to the pathophysiology of the osteoporotic syndrome that results from the loss of ovarian function, is a matter of speculation. Nevertheless, it is widely accepted that osteoblastic cells, in addition to being directly responsible for bone formation, control the bone resorption process by regulating the proliferation, differentiation, and recruitment of osteoclast progenitors (40). Osteoblasts mediate the bone-resorbing effects of systemic hormones such as PTH and $1,25(\mathrm{OH})_{2} \mathrm{D}_{3}$, as well as the effects of bone-resorbing cytokines such as IL-1 and TNF, which do not directly activate osteoclasts $(41,42)$. Besides osteoblasts, it has recently been shown that cultured stromal cells derived from the bone marrow support osteoclast-like cell formation from hematopoietic progenitor cells (43).

The hallmark of the skeletal changes ensuing upon the menopause is an imbalance of bone resorption over bone formation, leading to reduction of skeletal mass (44). Considering this, and the fact that estrogen-replacement therapy reduces the activity of the osteoclast with no immediate effect on the rate of bone formation (45), it is reasonable to expect that the effects of estrogens on bone must be exerted primarily on the resorption phase. In studies of ours reported elsewhere (46), we found that a dramatic bone loss induced by ovariectomy in mice is associated with increased osteoclast development in ex vivo bone marrow cell cultures, and is reversed by estrogen replacement, exactly as would be expected if estrogens regulate osteoclast progenitor formation. These findings confirm similar observations by Kalu (47).

In view of the above, we suggest that the demonstration of the inhibition of IL- 6 by estrogens in osteoblasts and bone marrow stromal cells provide evidence for a mechanistic paradigm that supports the following general hypothesis: bone and bone marrow cells produce cytokines, such as IL-6, which act in a paracrine fashion in the microenvironment of bone to regulate osteoclast formation. The production and/or action of these cytokines is under the inhibitory control of estrogens; hence, the bone loss associated with estrogen withdrawal might be due, at least in part, to the removal of these inhibitory effects. This hypothesis is in line with the well-appreciated fact that osteoporotic changes occur primarily in sites where bone comes into contact with the bone marrow $(48,49)$. We believe that this hypothesis provides new avenues of investigation that should improve our understanding of the bone protective effect of estrogens.

\section{Acknowledgments}

The authors would like to thank Dr. C. Slemenda and Terry Reister for the statistical analysis of the data; Dr. Gunther Derrigs, Theresa Nahreini Gem Burgess, and Teresa Burke for technical assistance; Drs. C. Johnston, H. Broxmeyer, and T. Garvey for their critical review of this paper; and Mrs. Denise Bardonaro for excellent secretarial support in the preparation of the manuscript.

This work was supported by grants from the National Institutes of Health AR 41313, AI 21761, and CA 45571, and the Department of Veterans Affairs. Dr. Girasole was supported by the Walther Oncology Center, Indianapolis, IN.

\section{References}

1. Lindsay, R., J. M. Aitken, J. B. Anderson, D. M. Hart, E. R. MacDonald, and A. C. Clark. 1976. Longterm prevention of postmenopausal osteoporosis by estrogen: evidence for an increased bone mass after delayed onset of estrogen treatment. Lancet. 1:1038-1041.

2. Barzel, U.S. 1988. Estrogens in the prevention and treatment of postmenopausal osteoporosis: a review. Am. J. Med. 85:847-850.

3. Komm, B. S., C. M. Terpening, D. J. Benz, K. A. Graeme, A. Gallegos, M. Korc, G. L. Greene, B. W. O'Malley, and M. R. Haussler. 1988. Estrogen bind- 
ing, receptor mRNA, and biologic response in osteoblast-like osteosarcoma cells. Science (Wash. DC). 241:81-84.

4. Eriksen, E. R., D. S. Colvard, N. J. Berg, M. L. Graham, K. G. Mann, T. C. Spelsberg, and B. L. Riggs. 1988. Evidence of estrogen receptors in normal human osteoblast-like cells. Science (Wash. DC). 241:84-86.

5. Gray, T. K., T. C. Flynn, K. M. Gray, and L. M. Nabell. 1987. 17 $\beta$-estradiol acts directly on the clonal osteoblast cell line UMR 106. Proc. Natl. Acad. Sci. USA. 84:6267-6271.

6. Ernst, M., J. K. Heath, and G. A. Rodan. 1989. Estradiol effects on proliferation, messenger ribonucleic acid for collagen and insulin-like growth factor-I, and parathyroid hormone-stimulated adenylate cyclase activity in osteoblastic cells from calvariae and long bones. Endocrinology. 125:825-833.

7. Fukayama, S., and A. H. Tashjian, Jr. 1989. Direct modulation by estradiol of the response of human bone cells (SaOS-2) to human parathyroid hormone (PTH) and PTH-related protein. Endocrinology. 124:397-401.

8. Kurihara, N., T. Suda, Y. Miura, H. Nakauchi, H. Kodama, K. Hiura, Y. Hakeda, and M. Kumegawa. 1989. Generation of osteoclasts from isolated hematopoietic progenitor cells. Blood. 74:1295-1302.

9. Kahn, A. J. and D. J. Simmons. 1975. Investigation of the cell lineage in bone using a chimera of chick and quail embryonic tissue. Nature (Lond.). 258:325-327.

10. Scheven, B. A. A., J. W. M. Visser, and P. J. Nijweide. 1986. In-vitro osteoclast generation from different bone marrow fractions, including a highly enriched haematopoietic stem cell population. Nature (Lond.). 321:79-81.

11. Owen, M. 1985. Lineage of osteogenic cells and their relationship to the stromal system. In Bone and Mineral Research. W. A. Peck, editor. Elsevier, Amsterdam. 3:1-24.

12. Boyce, B. F., T. B. Aufdemorte, I. R. Garrett, A. J. P. Yates, and G. R. Mundy. 1989. Effects of interleukin-1 on bone turnover in normal mice. Endocrinology. 125:1142-1150.

13. Johnson, R. A., B. F. Boyce, G. R. Mundy, and G. D. Roodman. 1989. Tumors producing human tumor necrosis factor induced hypercalcemia and osteoclastic bone resorption in nude mice. Endocrinology. 124:1424-1427.

14. Gowen, M., D. D. Wood, E. J. Ihrie, M. K. B. McGuire, R. Graham, and G. Russell. 1983. An interleukin-1-like factor stimulates bone resorption in-vitro. Nature (Lond.). 306:378-380.

15. Bertolini, D. R., G. E. Nedwin, and T. S. Bringman, D. D. Smith, and G. R. Mundy. 1986. Stimulation of bone resorption and inhibition of bone formation in-vitro by human tumour necrosis factors. Nature (Lond.). 319:516-518.

16. Pfeilschifter, J., C. Chenu, A. Bird, G. R. Mundy, and G. D. Roodman 1990. Interleukin-1 and tumor necrosis factor stimulate the formation of human osteoclastlike cells in-vitro. J. Bone Miner. Res. 4:113-118.

17. Kishimoto, T. 1989. The biology of interleukin-6. Blood. 74:1-10.

18. Michalevicz, R., D. Lifshitz, M. Revel. 1989. Interferon- $\beta$ 2/interleukin-6 and interleukin-3 synergize in stimulating proliferation of human early hematopoietic progenitor cells. Scanning Microsc. 3:1143-1150.

19. Kurihara, N., C. Civin, G. D. Roodman. 1991. Osteotropic factor responsiveness of highly purified populations of early and late precursors for human multinucleated cells expressing the osteoclast phenotype. J. Bone Miner. Res. 6:257-261.

20. Lowik, C. W. G. M., G. van der Pluijm, H. Bloys, K. Hoekman, O. L. M Bijvoet, L. A. Aarden, and S. E. Papapoulos. 1989. Parathyroid hormone (PTH) and PTH-like protein (PLP) stimulate interleukin-6 production by osteogenic cells: a possible role of interleukin-6 in osteoclastogenesis. Biochem. Biophys. Res. Commun. 162:1546-1552.

21. Feyen, J. H. M., P. Elford, F. E. DiPadova, and U. Trechsel. 1989. Interleukin- 6 is produced by bone and modulated by parathyroid hormone. J. Bone Miner. Res. 4:633-638.

22. Ishimi, Y., C. Miyaura, C. H. Jin, T. Akatsu, E. Abe, Y. Nakamura, A. Yamaguchi, S. Yoshiki, T. Matsuda, T. Hirano, T. Kishimoto, and T. Suda. 1990. IL-6 is produced by osteoblasts and induces bone resorption. J. Immunol. 145:3297-3303.

23. Black, K., I. R. Garrett, and G. R. Mundy. 1991. Chinese hamster ovarian cells transfected with the murine interleukin- 6 gene cause hypercalcemia as well as cachexia, leukocytosis and thrombocytosis in tumor-bearing nude mice. Endocrinology. 128:2657-2659.

24. Tabibzadeh, S. S., U. Santhanam, P. B. Sehgal, and L. T. May. 1989. Cytokine-induced production of IFN- $\beta_{2} /$ IL -6 by freshly explanted human endometrial stromal cells. Modulation by estradiol-17ß. J. Immunol. 142:3134-3139.

25. Graves III, L. and R. L. Jilka. 1990. Comparison of bone and parathyroid hormone as stimulators of osteoclast development and activity in calvarial cell cultures from normal and osteopetrotic (mi/mi) mice. J. of Cell. Physiol. 145:102-109.

26. Boswell, H. S., D. Y. Mochizuki, G. S. Burgess, S. Gillis, E. B. Walker, and D. E. Williams. 1990. A novel mast cell growth factor (MCGF-3) produced by marrow-adherent cells that synergizes with IL-3 and IL-4. Exp. Hematol. (NY). 18:794-800.
27. Williams, D. E., J. Eisenman, A. Baird, K. Van Ness, C. Rauch, L. S. Park, U. Martin, D. Y. Mochizuki, C. J. March, H. S. Boswell, G. S. Burgess, D. Cosman, and S. D. Lyman. 1990. Identification of a ligand for the c-kit proto-oncogene. Cell. 63:167-174

28. Zipori, D., J. Toledo, and K. Von der Mark. 1985. Phenotypic heterogeneity among stromal cell lines from mouse bone marrow disclosed in their extra cellular matrix composition and interaction with normal and leukemic cells. Blood. 66:447-455.

29. Williams, D. C., G. B. Boder, R. E. Toomey, D. C. Paul, C. C. Hillman K. L. King, R. M. VanFrank, and C. C. Johnston, Jr. 1980. Mineralization and metabolic response in serially passaged adult rat bone cells. Calcif. Tissue Int. 30:233-246.

30. Sudo, H., H-A. Kodama, Y. Amagai, S. Yamamoto, and S. Kasai. 1983. In vitro differentiation and calcification in a new clonal osteogenic cell line derived from newborn mouse calvaria. J. Cell Biol. 96:191-198.

31. Jilka, R. L. 1986. Parathyroid hormone-stimulated development of osteoclasts in cultures of cells from neonatal murine calvaria. Bone (Elmsford). 7:2940.

32. Aarden, L. A., P. M. Lansdorp, and E. R. de Groot. 1985. A growth factor for B cell hybridomas produced by human monocytes. Lymphokines. 10:175185.

33. Chomczynski, P., and N. Sacchi. 1987. Single-step method of RNA isolation by acid quanidinium thiocyanate-phenol-chloroform extraction. Anal. Biochem. 162:156-159.

34. Harpold, M. M., R. M. Evans, M. Salditt-Georgieff, and J. E. Darnell. 1979. Production of mRNA in chinese hamster cells: relationship of the rate of synthesis to the cytoplasmic concentration of nine specific mRNA sequences. Cell. 17:1025-1035.

35. Matsumoto, T., C. Igarashi, Y. Takeuchi, S. Harada, T. Kikuchi, H. Yamato, and E. Ogata. 1991. Stimulation by 1,25-dihydroxyvitamin $\mathrm{D}_{3}$ of in-vitro mineralization induced by osteoblast-like MC3T3-E1 cells. Bone (Elmsford). 12:27-32.

36. Horowitz, M. C., D. L. Coleman, P. M. Flood, T. S. Kupper, and R. L. Jilka. 1989. Parathyroid hormone and lipopolysaccharide induce murine osteoblast-like cells to secrete a cytokine indistinguishable from granulocyte-macrophage colony-stimulating factor. J. Clin. Invest. 83:149-157.

37. Kurihara, N., D. Bertolini, T. Suda, Y. Akiyama, and G. D. Roodman. 1990. IL-6 stimulates osteoclast-like multinucleated cell formation in long term human marrow cultures by inducing IL-1 release. J. Immunol. 144:4226-4230.

38. Al-Humidan, A., S. H. Ralston, D. E. Hughes, K. Chapman, L. Aarden, R. G. G. Russell, and M. Gowen. 1991. Interleukin-6 does not stimulate bone resorption in neonatal mouse calvariae. J. Bone Miner. Res. 6:3-8.

39. Elias, J. A. and V. Lentz. 1990. IL-1 and tumor necrosis factor synergistically stimulate fibroblast IL-6 production and stabilize IL-6 messenger RNA. $J$. Immunol. 145:161-166.

40. Takahashi, N., T. Akatsu, N. Udagawa, T. Sasaki, A. Yamaguchi, J. M. Moseley, T. J. Martin, and T. Suda. 1988. Osteoblastic cells are involved in osteoclast formation. Endocrinology. 123:2600-2602.

41. McSheehy, P. M. J., and T. J. Chambers. 1986. Osteoblastic cells mediate osteoclastic responsiveness to parathyroid hormone. Endocrinology. 118:824828 .

42. Thompson, B. M., G. R. Mundy, and T. J. Chambers. 1987. Tumor necrosis factors A and B induce osteoblastic cells to stimulate osteoclastic bone resorption. J. Immunol. 138:775-779.

43. Hattersley, G., and T. J. Chambers. 1989. Generation of osteoclasts from hemopoietic cells and a multipotential cell line in-vitro. J. Cell. Physiol. 140:478482.

4. Riggs B. L., Melton, L. J. 1986. Involutional osteoporosis. N. Engl. J. Med. 314:1676-1686.

45. Riggs, B. L., J. Jowsey, P. J. Kelly, J. D. Jones, and F. T. Maher. 1969. Effect of sex hormones on bone in primary osteoporosis. J. Clin. Invest. 48:10651072.

46. Girasole, G., D. Paul, G. Passeri, J. Herring, R. L. Jilka, S. C. Manolagas, and D. C. Williams. 1991. Increased osteoclast-like cell formation from bone marrow aspirates and trabecular bone loss are induced by ovariectomy and reversed by estrogen replacement in the mouse. J. Bone Miner. Res. 6(Suppl. 1):299a. (Abstr.)

47. Kalu, D. N. 1990. Proliferation of tartrate-resistant acid phosphatase positive multinucleate cells in ovariectomized animals. Proc. Soc. Exp. Biol. Med. 195:70-74.

48. Frost, H. M. 1966. Bone Dynamics in Osteoporosis and Osteomalacia. Springfield, Springfield, IL.

49. Frost, H. M. 1973. Bone Remodeling and its Relation to Metabolic Bone Disease. Springfield, Springfield, IL.

50. Miliken, G. E., and D. E. Johnson. 1984. Analysis of Messy Data. Van Nostrand Reinhold, New York. 126-195. 